\title{
Classification of underground mining works within the Tg. Ocna salt mine from the point of view of gas emissions
}

\author{
Adrian Matei ${ }^{1 *}$, and Nicolae Ianc ${ }^{1}$ \\ ${ }^{1}$ National Institute for Research and Development in Mine Safety and Protection to Explosion - \\ INSEMEX, 32-34 G-ral Vasile Milea Street, Petroșani, Hunedoara, Romania
}

\begin{abstract}
According to the new classification method, salt mines and underground work or areas where methane has not been observed but for which methane has been observed in boreholes found in rock massifs are considered to be fire mines / mine areas or mining work. This new classification allows only the effective areas of exploitation to be maintained in the wire regime, the rest of the salt mine being considered non-wire. The purpose of this paper is to determine the rate of methane (explosive gas) and carbon dioxide (oxidizing gas) in the mining operations of the $\mathrm{Tg}$-Ocna salt mine, given its classification.
\end{abstract}

\section{Introduction}

The purpose of this paper is to establish the regime of methane emissions (explosive gas) and carbon dioxide emissions (asphyxiating gas) in underground working mines within the Tg. Ocna Salt Mine / mine sections, in order to classify it.

The need for a new classification arose with the loss of the validity of the "Labor Protection Norms for Salt" and the "Labor Protection Law No. 90/1996" and the appearance of the "Law on Safety and Health at Work No. 319/2006"'[5].

The following elements have been taken into account for the preparation of this paper:

- the geological and technical-mining conditions of the salt deposit from the mining perimeter Tg. Ocna;

- the existing records and documentations regarding the previous gas appearances and their manifestation mode;

- the results of quantitative and qualitative measurements of underground mining works on:

a) circulated flows;

b) concentrations of methane and carbon dioxide;

c) the absolute flows recorded;

d) gas storage capacity;

e) mass concentration and gas pressure.

\footnotetext{
*Corresponding author: adrian.matei@insemex.ro
} 
According to the new classification methodology, salt pans and underground works or areas thereof in which the presence of methane in the underground atmosphere was not found but in which the presence of methane is found in the test holes drilled in the rock mass is considered to be mine / areas in mine or gassy underground works. This new classification allows the preservation in gassy regime only of the proper exploitation areas (work fronts), the rest of the salt mine being considered as blackish.

\section{Classification procedures}

The classification of mines is carried out at the request of the economic unit by an authorized specialized institute, which draws up the classification or verification documentation of the classification.

The classification verification documentation may also be prepared by the economic agent, in which case it will be approved by an authorized specialized institute.

The verification of the classification is carried out whenever there are changes in the emission of gases (methane or carbon dioxide) and obligatorily every 2 years.

Coal and bituminos shales mines, which have been classified as gassy, cannot be included in the category of non-gassy mines.

The classification and verification documentation of the classification will be appropriated by the coordinating body of the economic unit and will be approved by the Ministry of Labor and Social Protection.

In case of maintaining the employment category, the classification verification documentation is endorsed by an authorized specialized institute, following that the coordinating body of the economic agent to notify the Ministry of Labor and Social Protection.

The classification and verification documentation shall include:

a) technical memorandum for the presentation of the mine (underground mining works);

b) the results of the study of gas emissions (underground measurements, analyzes, specialized documentation, etc.), which determine the classification;

c) the updated graphic part;

d) the classification or verification verification of the classification, issued by the authorized specialized institute.

Measurements for the classification of mines as well as periodic inspections shall be carried out as follows:

A. In relation to methane releases:

a) The presence of methane in the secondary and main currents of exhaust air from the mine is controlled.

b) If, in the exhaust currents of the contaminated air, the presence of methane has not been detected, it will proceed to measure its content in the underground atmosphere of the workplaces, with the appropriate detection equipment, in the areas where it is possible to accumulate of this gas.

c) If the presence of methane has not been detected by these measurements, within the limits of the accuracy of the equipment used, it shall be detected in a working front at the bottom of the bag with tectonic disturbances, with ascending advance, located at the lower level of mine. The measurements shall be performed after the partial ventilation system has been switched off for a maximum of 24 hours. If the methane concentration has reached $2 \%$ by volume, the measurements will be stopped and the ventilation system will be partially restored.

d) If the presence of methane has not been found in the underground atmosphere, it is investigated in the massif of useful rock. For this purpose, three test holes with a maximum 
length of $3 \mathrm{~m}$ each will be made, located on the surface of the front. Geological survey wells, made in or towards the coal seam, may also be used for the same purpose.

After drilling the test holes, a gas collection probe is placed in them and sealed accordingly.

The concentration of gases accumulated in the isolated space of the test hole is determined with the appropriate detection equipment, within 24 hours of their sealing.

B. In relation to carbon dioxide emissions:

a) The presence of carbon dioxide in the secondary and main air exhaust currents is checked.

b) If the presence of carbon dioxide in the exhaust streams, in a concentration of at least $1 \%$ by volume, has not been detected, the presence of this gas in a working front at the bottom of the bag with tectonic disturbances, with downward advancement, shall be continued. descending (or in a horizontal work), located at the lower level of the mine. In these work fronts, the determination of the carbon dioxide concentration is made after the partial aeration installation has been stopped for 24 hours and only by teams equipped with life-saving insulating devices.

In order to establish the category of mine (I and II) according to the relative flow of methane, the air flows and the percentage concentrations of methane in the main flowing air exhaust currents shall be measured.

The methane concentration shall be determined with the appropriate measuring equipment, based on at least two measurements, provided that the difference between two determinations does not exceed the measurement error of the equipment used, indicated by the manufacturer. Otherwise, the operation is repeated.

The detection of the presence of methane in the exhaust air currents requires the performance of specific measurements, as follows:

a) during a calendar month, three measurements at intervals of 10 days, each measurement being performed on a normal working day;

b) the measurements shall be performed in all main air exhaust currents, in each shift of the day, in the second half of the shift.

The relative flow of methane $(\mathrm{q}(\mathrm{r})$ ) specific to a main ventilation station is determined by the relation:

$$
\mathrm{q}(\mathrm{r})=\frac{q(a)}{T},\left(\mathrm{~m}^{3} / \mathrm{t}\right)
$$

where: $\mathrm{q}(\mathrm{a})=$ absolute maximum methane flow ( $\mathrm{m} 3 / \mathrm{min}$.$) ;$

$\mathrm{T}=$ production in tonnes in the month (period) in which the measurements were made.

The absolute maximum methane flow will be calculated with the relation:

$$
\mathrm{q}(\mathrm{a})=\frac{31 \cdot 24 \cdot 60 \cdot(Q 1 C 1+Q 2 C 2+Q 3 C 3)}{3 \cdot 100}
$$

in which: Q1, Q2, Q3 ( $\mathrm{m} 3 / \mathrm{min}$.) and $\mathrm{C} 1, \mathrm{C} 2, \mathrm{C} 3$ (\% in vol.) represent the air flows, respectively the methane concentrations measured in the mining work for the evacuation of the vitiated air, in the three shifts. In the case of activity carried out in four shifts, four measurements will be performed (flow rate, methane concentration).

In the case of mines with several main ventilation stations, the flow rate relative to the maximum value will be taken into account when determining the mine category [7]. 


\section{General considerations regarding the geology of the deposit and the mining perimeter}

Mining works serving Tg. Ocna saline, are located in the salt massif of Fețele Târgului located near the town of Tg. Ocna, on the left bank of the Trotuş river.

From a geological point of view, the region is located in the contact area between the middle-marginal unit of the miocene and the extreme unit of this geological formation.

The rock salt deposit from Tg. Ocna is represented by lower miocene deposits which, due to an internal tectonics, form a fold of salt, so that in the bed as well as in the roof of the salt appear lower Miocene deposits. The salt massif is predominantly homogeneous in which sterile intercalations occur (clays, marls and impure salt) [1].

A sterile intercalation has been identified at the level of horizon III and which extends in depth with the tendency to move to SE. From a tectonic point of view, the salt massif is limited to the west by an almost vertical fault with the NS direction. To the east, the saliferous formation is bordered by a fault of medium inclination along which the salt comes in contact with the deposits of the upper helvetian consisting of gypsum, marl, sandstone and tufa marl. In the northern part it is affected by a transverse fault that separates the salt massif into two compartments, of which the southern compartment is the object of exploitation.

In addition to the overall tectonics, the salt deposit is affected by an intimate tectonics that caused intense creases, rolling and thickening. Under these conditions, a series of sterile intercalations were also included in the salt mass. However, the salt from Tg. Ocna is clean and contains approx. $98 \% \mathrm{NaCl}$.

\subsection{Opening, preparation and exploitation of mining field}

The Trotuș mine was opened in 1969 through a coastal gallery I 101, executed at the level of horizon II.

The gallery was dug in the tailings, with a profile of $13.5 \mathrm{~m}^{2}$ and supported in vaulted masonry. At the entrance to the salt massif, the gallery was enlarged to a profile of $32 \mathrm{~m}^{2}$. For the deep opening of the lower horizon the gallery was continued with a spiral inclined plane, at an identical profile.

For the realization of the aeration, a concrete aeration well (with a section of $7.5 \mathrm{~m}^{2}$ ) of roughly $131 \mathrm{~m}$ depth is used. It connects to the aeration suite 204 , which is deepened with the exploitation of new horizons.

Subsequently, in order to increase the transport capacity, a new coastal gallery ( Unirea Gallery) was built to open horizon VII, which was continued with an inclined plan following the level of exploitation, on which the salt is transported to the preparation plant with the help of conveyor belts.

The first mention of salt exploitation in Tg Ocna was in 1595.

Salt mining was carried out in bell-shaped chambers (until 1875) and continued in trapezoidal chambers (Old Moldova and New Moldova mines). Since 1970, the salt has been exploited with "small rooms and abandoned square pillars". The exploitation is descending on horizons[3].

At the beginning of the operation, the rooms were $16 \mathrm{~m}$ wide and $8 \mathrm{~m}$ high, and the pillars had a side of $14 \mathrm{~m}$. Currently the rooms have roughly $13.75 \mathrm{~m}$ wide and $8 \mathrm{~m}$ high vault, and the pillars have a side of $16.25 \mathrm{~m}$. Between the horizons there is a floor $8 \mathrm{~m}$ thick. The pillars are perfectly superimposed (coaxial).

The deviation of the salt is done by executing a track, at the hearth of the chamber with kerving machine, after which the demolition in the front is carried out through mine holes and the shooting with explosive. The dumped salt is loaded into dump trucks and transported 
to the silo on the $\mathrm{X}$ horizon from where it is discharged onto the conveyor belts and discharged to the surface[2].

\subsection{The mine's ventilation system}

The general ventilation of the Tg Ocna salt mine is carried out trough a aspiration system, by means of three main ventilation installations (motor-fan unit), located on the surface, in the ventilation shaft channel.

An aeration system is equipped with a double suction centrifugal fan type V562-00 DA, having the following characteristics:
- debit
$5880 \mathrm{~m}^{3} / \mathrm{min}$;
- depression
$130 \mathrm{~mm} \mathrm{col} \mathrm{H}_{2} \mathrm{O}$;
- speed
$600 \mathrm{rev} / \mathrm{min}$.

being driven by an engine having the following characteristics:

- power $319 \mathrm{kw}$;

- speed $590 \mathrm{rev} / \mathrm{min}$;

- supply voltage $6000 \mathrm{~V}$.

The other two installations are equipped with axial fans type VOKD-1,5, having the following nominal parameters:
- debit
$3180 \mathrm{~m}^{3} / \mathrm{min}$;
- depression
$318 \mathrm{~mm} \mathrm{H}_{2} \mathrm{O}$;
- speed
$960 \mathrm{rot} / \mathrm{min}$.
being driven by engines with several technical characteristics:
- power
$160 \mathrm{kw}$;
- speed
- supply voltage
$980 \mathrm{rev} / \mathrm{min}$;
$380 \mathrm{~V}$.

The entry of fresh air into the salt mine is made on the two coastal galleries. The flow direction is descending, it washes the operating horizons, being directed on short ventilation suites, under the influence of the depression created by the fan and is evacuated on the ventilation gallery to the surface on the ventilation shaft[6].

\section{Measurements performed in underground mining works}

In order to establish the gas release regime, respectively the classification category, depending on the absence or presence of methane and carbon dioxide, quantitative and qualitative measurements were performed in the main and secondary streams of exhaust air from the salt mine, in active mining works, inactive and in reserve.

In addition to these, specific measurements were made to determine the presence of methane gas and during the performance of technological operations at the operating chambers:

- drilling of mine holes in the salt massif;

- execution of the track at the base of the work fronts;

- measuring gas concentrations in the work front, in the ceiling of the rooms and in the general air evacuation currents from the horizons and mine.

The measurements in the active mining works were also carried out in the case of a preparation work in which the partial aeration was stopped for 24 hours.

The investigation of the presence of methane gas in the salt massif around the mining works was carried out through test holes in which gas collection wells were introduced. These were sealed for 24 hours. Also for this purpose, measurements were performed in a horizontal drilling performed towards the salt-tailings limit and in the bottoms of mine holes left after the firing of the working fronts. 


\section{Results of measurements performed}

The results obtained following the measurements and determinations performed in the underground atmosphere and in the salt massif, shown in tables no. 1-2, highlighted the following:

- the absence of methane in the main and secondary currents of air evacuation from the mine;

- the absence of methane during the development of technological processes such as: drilling of test holes and baking of work fronts or after shooting stops in work fronts;

- absence of methane in the underground atmosphere in case of partial shutdown of the aeration installation;

- the presence of methane in the salt massif around the mining works and in the marginal sterile rocks (test holes and drillings), at the salt cutting works with kerving machine and works for shooting the work fronts;

- the absence of carbon dioxide in the atmosphere of mining works and its presence in the salt massif;

- lack of gas pressure in the test holes made in the salt massif;

- no blows or other gas manifestations were reported[4].

Table 1 Gas concentrations in the underground atmosphere of jobs - Trotuş mine

\begin{tabular}{|c|c|c|c|c|c|c|c|c|c|}
\hline \multirow{3}{*}{$\begin{array}{l}\text { No } \\
\text {. } \\
\\
0 .\end{array}$} & \multirow{3}{*}{$\begin{array}{l}\text { Name of the } \\
\text { mining } \\
\text { work }\end{array}$} & \multirow{3}{*}{ 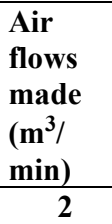 } & \multicolumn{4}{|c|}{$\begin{array}{l}\text { Composition of the } \\
\text { underground atmosphere } \\
\text { (\% vol.) }\end{array}$} & \multicolumn{2}{|c|}{ 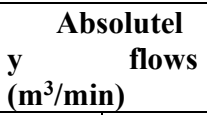 } & \multirow[t]{3}{*}{$\begin{array}{ll} & \text { Remark } \\
\text { s } & \end{array}$} \\
\hline & & & CO & \multirow{2}{*}{$\begin{array}{r}\mathrm{O}_{2} \\
4\end{array}$} & \multicolumn{2}{|c|}{$\mathrm{CH}_{4}$} & \multirow{2}{*}{$\begin{array}{r}\mathrm{CO}_{2} \\
7\end{array}$} & \multirow{2}{*}{$\begin{array}{r}\mathrm{CH}_{4} \\
8\end{array}$} & \\
\hline & & & 3 & & 5 & 6 & & & \\
\hline 1. & $\begin{array}{l}\text { COAST } \\
\text { GALLERY I } \\
101 \\
\end{array}$ & 349 & 0 & 20.9 & 0 & 0 & -- & -- & $\begin{array}{l}\text { fresh air } \\
\text { inlet }\end{array}$ \\
\hline 2. & $\begin{array}{l}\text { UNIREA } \\
\text { GALLERY }\end{array}$ & 24 & 0 & 20.9 & 0 & 0 & -- & -- & \\
\hline 3. & $\begin{array}{l}\text { BASE } \\
\text { FOLLOWE } \\
\text { R } \\
204 \quad \text { Horiz. } \\
\text { VIII }\end{array}$ & $8^{341}$ & 0.1 & 20.4 & 0 & 0 & 3.41 & - & $\begin{array}{l}\text { general } \\
\text { output foul } \\
\text { air, under the } \\
\text { suite }\end{array}$ \\
\hline 4. & $\begin{array}{l}\text { HORIZON } \\
\mathrm{X}\end{array}$ & 174 & 0.2 & 20.4 & 0 & 0 & 3.48 & -- & $\begin{array}{l}\text { horizon } \\
\text { access door } \\
\text { half open }\end{array}$ \\
\hline 5. & $\begin{array}{l}\text { Inclined } \\
\text { plane } \\
\quad 521 \\
\text { HORIZON } \\
\text { XI }\end{array}$ & 357 & 0 & 20.6 & 0 & 0 & -- & -- & $\begin{array}{l}\text { X } \\
\text { horizon } \\
\text { access doors } \\
\text { closed }\end{array}$ \\
\hline
\end{tabular}




\begin{tabular}{|c|c|c|c|c|c|c|c|c|c|}
\hline 6. & $\begin{array}{l}\text { AERIAL } \\
\text { WELL } \\
\text { CHANNEL }\end{array}$ & $\begin{array}{r}362 \\
2\end{array}$ & 0.1 & 20.4 & 0 & 0 & 3.62 & $\begin{array}{l}- \\
--\end{array}$ & $\begin{array}{l}\text { total stale } \\
\text { foul air }\end{array}$ \\
\hline
\end{tabular}

Table 2 Gas concentrations in the salt massive around the mining works - Trotuş mine

\begin{tabular}{|c|c|c|c|c|c|c|c|c|c|}
\hline \multirow{3}{*}{$\begin{array}{l}\text { Crt.No } \\
\text {. }\end{array}$} & \multirow{3}{*}{$\begin{array}{l}\text { Name of } \\
\text { the } \\
\text { mining } \\
\text { work }\end{array}$} & \multirow{3}{*}{$\begin{array}{l}\text { The } \\
\text { rock } \\
\text { he } \\
\text { drille } \\
\text { d into }\end{array}$} & \multirow{3}{*}{$\begin{array}{lr}\text { Sampl } \\
\text { e } & \text { hole } \\
\text { number }\end{array}$} & \multicolumn{6}{|c|}{ Measured gas concentration (\% vol.) } \\
\hline & & & & \multicolumn{3}{|c|}{ Before sealing } & \multicolumn{3}{|c|}{ After sealing } \\
\hline & & & & $\mathrm{CO}_{2}$ & $\mathbf{O}_{2}$ & $\mathrm{CH}_{4}$ & $\mathrm{CO}_{2}$ & $\mathbf{O}_{2}$ & $\mathrm{CH}_{4}$ \\
\hline $\mathbf{0}$ & 1 & 2 & 3 & 4 & 5 & 6 & 7 & 8 & 9 \\
\hline 1. & $\begin{array}{l}\text { Room No. } \\
6193 \\
\text { Horiz. X }\end{array}$ & salt & $\begin{array}{l}\text { Drilling } 261 \\
(68 \quad \mathrm{~m} \\
\text { length) }\end{array}$ & 0.2 & 16.5 & 0.0018 & 0.2 & 18.1 & 2.1 \\
\hline 2. & $\begin{array}{l}\text { Room } \\
253 \\
\text { Horiz. XII }\end{array}$ & salt & $\begin{array}{l}\text { In the } \\
\text { shotgun } \\
\text { hole in the } \\
\text { ceiling }\end{array}$ & 0.1 & 20.8 & 0.0004 & 0.1 & 19.7 & 1.4 \\
\hline \multirow[t]{4}{*}{3.} & \multirow{4}{*}{$\begin{array}{l}\text { Room } \\
201 \\
\text { Horiz. } \\
\text { XII }\end{array}$} & salt & G. 1 & 0,1 & 20.6 & 0.0007 & 0.1 & 19.1 & 1.1 \\
\hline & & salt & G.2 & 0.1 & 20.5 & 0.2 & 0.1 & 18.1 & 2.2 \\
\hline & & salt & G.3 & 0.1 & 20.2 & 0.5 & 0.1 & 19.0 & 1.38 \\
\hline & & salt & G.4 & 0.1 & 20.4 & 0.2 & 0.1 & 14.1 & 8.0 \\
\hline \multirow[t]{3}{*}{4.} & \multirow{3}{*}{$\begin{array}{l}\text { Room No. } \\
6232 / 624 \\
5 \text { Horiz } \\
\text { XI }\end{array}$} & salt & G.1 & 0 & 20.8 & 0.0002 & \multirow{3}{*}{\multicolumn{3}{|c|}{ In the shot holes }} \\
\hline & & salt & G.2 & 0 & 20.8 & 0.0005 & & & \\
\hline & & salt & G.3 & 0 & 20.9 & 0.0007 & & & \\
\hline 5. & $\begin{array}{l}\text { Room No. } \\
6210, \\
\text { Horiz. X }\end{array}$ & salt & & 0.1 & 20.8 & 0 & $\begin{array}{r}\mathrm{C} \\
\text { block }\end{array}$ & tting & salt \\
\hline \multirow[t]{2}{*}{6.} & $\begin{array}{l}\text { Room } \\
253\end{array}$ & salt & $\begin{array}{l}\text { Fresh } \\
\text { cut }\end{array}$ & 0.1 & 20.5 & $\begin{array}{ll} & 0.3 \\
5 & \end{array}$ & \multirow{2}{*}{\multicolumn{3}{|c|}{ Path cutting machine }} \\
\hline & Horiz. XII & & Old cut & 0.1 & 20.7 & 0.0018 & & & \\
\hline
\end{tabular}

\section{Conclusions}

The measurements, determinations and observations performed by INSEMEX Petroșani in the year 2021, highlighted the following:

1. Absence of methane in the main and secondary currents of exhaust air from the mine; 
2. Absence of methane in the work fronts and in the active, inactive and reserve mining works;

3. The presence of methane in the test holes near the salt-sterile contact area;

4. The presence of methane in the prospecting drilling in concentrations of $0.0018-2.1 \%$ vol.;

5. The presence of methane in the test holes after sealing for 24 hours in concentrations between 1.1 and $8 \%$ vol.

6. Presence of carbon dioxide in the test holes with values of $0-0.1 \%$ vol ;

7. The presence of carbon dioxide in the main and secondary currents of exhaust air, as well as in the active and inactive work fronts in maximum value is $0.1 \%$ vol.

8. Taking into account the results of measurements, determinations and observations performed by INSEMEX Petroșani in the underground mining works at Tg. Ocna Salt Mine, during 2021, in conjunction with the measurements from previous years and the mine categorization, it is proposed:

9. Maintenance of the Trotuș mine within the Târgu Ocna Salt Mine in the category of "non-gassy" mines after the methane releases of the active, inactive and in reserve mining works under the depression created by the main aeration station;

10. Maintaining the Trotuș mine in the "gassy category I" regime, of:

- ventilated work fronts with the help of partial ventilation installations at the bottom of the bag;

- work fronts where works are carried out: cutting of the spring, drilling the shooting holes, execution of the work of shooting the work front, loading the demolished material;

- chambers in which wells are drilled to investigate the salt deposit or sterile intercalations and the salt / tailings contact area.

11. Maintenance of the Trotuş mine in "CATEGORY I - a" in terms of carbon dioxide emissions.

\section{References}

1. E. Chiuzan, Verification of the classification of the Trotuş mine within the Tg. Ocna in terms of gas emissions.( INSEMEX 1998-2020)

2. E. Chiuzan, Establishing the regime of methane and carbon dioxide emissions in order to classify the Trotus mine belonging to the Tg Ocna Salt Mine (INSEMEX 1990-2000)

3. A. Matei, Verification of the classification of the Trotus mine within the Tg. Ocna in terms of gas emissions. (INSEMEX 2017-2021)

4. A. Matei, Establishing the regime of methane and carbon dioxide emissions in order to classify the Trotuş mine belonging to the Tg. Ocna Salt Mine (INSEMEX 2017-2021)

5 . $* * *$ Law on safety and health at work NO. 319/2006.

6 . *** Technical memorandum for the presentation of the Trotus mine within the Tg.Ocna.

7. $* * *$ Methodological rules on the classification of mines in terms of gas emissions. 